\title{
Scriptworlds Lost and Found
}

\author{
David Damrosch \\ Harvard University \\ ddamrosc@fas.harvard.edu
}

\begin{abstract}
When writing systems spread beyond their language of origin, they bring literacy to formerly oral cultures or intrude on or displace an existing system. The process of learning a new script often entails learning a good deal about the source culture and its literature, sometimes overwriting earlier local traditions, other times creatively stimulating them. This essay looks first at some of the literary consequences of the spread of cuneiform writing in relation to its hieroglyphic and alphabetic rivals in the ancient Near East, and then discusses the advance and later loss of Chinese script in Vietnam and Korea, in the examples of the foundational work of modern Vietnamese literature, Nguyen Du's The Tale of Kieu, and poems by the modern Korean poet Pak Tujin.
\end{abstract}

\section{Keywords}

scriptworlds - writing systems - cuneiform - Sinosphere - Nguyen Du - Pak Tujin

It was an archaeological map that first led me to think about the shaping force of writing systems on literary cultures. This was a map showing the various sites from which texts of The Epic of Gilgamesh have been recovered. Gilgamesh can fairly be called the first true work of world literature, as it circulated over many centuries far beyond its origins in southern Mesopotamia, and it is the earliest literary text known to have been translated into several languages. Portions of the epic have been found in Hittite and in Hurrian, and the Akkadian original itself is an expansive adaptation of an earlier Sumerian song cycle commissioned by King Shulgi of Ur (r. 2094-2047 BCE), the world's first known patron of literature. Gilgamesh appears, in fact, to have been the most popular literary hero of the ancient Near East; texts and related artifacts 
about him have been recovered so far from two dozen sites. These are located not only around Mesopotamia but eastward in the Elamite capital of Susa in what is now Iran, and as far away as the Hittite capital at Boghazköy in northern Anatolia and in the Canaanite stronghold of Megiddo, some fifty miles north of Jerusalem.

Looking at this map, I was struck not only by the extent of the epic's circulation but also by its limits: this most famous Mesopotamian text was bounded by - and almost co-extensive with - the spread of cuneiform writing. Every text about Gilgamesh that we have, written in four different languages (Sumerian, Akkadian, Hittite, and Hurrian) over the course of a millennium and a half from around 2100-1200 BCE, is in cuneiform. The fragment found at Megiddo had reached roughly the farthest point of cuneiform's daily use south of the Syrian city-state of Ugarit, a major center of cuneiform writing. Despite the epic's immense popularity across several languages and many centuries, there is no evidence that it was ever translated into any non-cuneiform script until after its recovery in the nineteenth century. In this respect The Epic of Gilgamesh is typical of all literary texts written in cuneiform, which vanished in the late first millennium $\mathrm{BCE}$, when people across the region became seduced by the ease of alphabetic writing and stopped inscribing wedge-shaped symbols on clay tablets. As the Assyriologist Andrew George has said, "the epic that we know died with the cuneiform writing system, along with the large portion of the scribal literature that was of no practical, scientific, or religious use in a world without cuneiform" (George, Babylonian Epic 1: 70).

I'll begin by outlining some key features of cuneiform and its rivals, as this long-lost set of nested scripts can provide suggestive comparisons for subsequent developments in East Asia. During the two and a half millennia of cuneiform's reign, political and economic affairs could be conducted in cuneiform even beyond the regions where the script was truly at home. A large cache of cuneiform tablets dating from the fourteenth century вСЕ, found at Amarna in northern Egypt in the 188os, shows that the pharaohs had scribes trained to read and write both in Akkadian and in Hittite, which was long used as a diplomatic language in the Levant. Yet no literary texts in cuneiform have been discovered at Amarna, and though several books of the Bible, such as Genesis and Job, show clear awareness of Babylonian literary predecessors, none contains any actual translation of a cuneiform text or passage. Throughout the ancient Near East, poems and prose narratives evidently circulated largely within the broader script system in which they were first composed. If this is so, it may be better to speak of The Epic of Gilgamesh as circulating around "the cuneiform scriptworld," rather than the smaller region of Mesopotamia or the larger territory of the ancient Near East. 
The Near East contained three principal literary systems, each based in a different script or family of scripts. Nearly as old as cuneiform writing were the elaborate Egyptian hieroglyphs, little used outside Egypt, and several societies along the eastern Mediterranean coast used variations of a West Semitic alphabetic system, principally comprising Hebrew, Aramaic, alphabetic Ugaritic, and Phoenician. ${ }^{1}$ The separations between these groups weren't watertight; scribes were often competent in more than one system, and the hieroglyphic and cuneiform systems themselves were markedly phonetic. Cuneiform had a syllabic base (with some signs used instead as logographs, for their sense rather than their sound), and the Egyptians early on began to use some two dozen hieroglyphics purely for their phonetic value (a foot standing for "b," a hand for "d," a feather for " $y$ "). A typical word in Egyptian is written with three signs expressing the word's triliteral base, followed by one or two ideographs indicating the category of objects to which the word belongs (a sun for words having to do with time, a little person in an appropriate pose for an occupation or emotion). In their mixture of phonetic and pictographic elements, cuneiform and hieroglyphics are comparable to the Chinese script, with its substantial phonetic dimension even amid its tens of thousands of characters. The West Semitic alphabetic systems actually derived from cursive forms of the phonetic hieroglyphs, and in Ugarit a purely alphabetic version of cuneiform was sometimes employed. Yet a reader trained only in the two dozen signs of alphabetic cuneiform would have no way at all to read the six hundred signs of syllabic cuneiform, the standard script used for Sumerian and Akkadian literature.

Conversely, though, as Gilgamesh's impressive distribution shows, a widespread writing system could open up boundaries of other sorts, easing a work's entry into new regions and new languages. A script also has subtle but farreaching effects on what is written to begin with. It is no coincidence that several of the recovered fragments of Gilgamesh were selections in school texts

1 Linguists often speak of the West Semitic alphabets as "abjads," considering them as not yet full alphabets, since these scripts recorded consonants and semi-vowels (y and w) but not full vowels. I prefer to regard them as true alphabets, as the nineteenth-century linguists who credited the Phoenicians and the Greeks with inventing the first "true" alphabets were all too interested in separating Classical—or even Aryan—culture from the unenlightened Semites. The Greek letters alpha and beta, the root of our term "alphabet," correspond directly to the Hebrew and Arabic aleph/alif and beth/bet at the head of their respective word-lists, and while the aleph and alif can carry a range of vowels, this is only a difference of degree from the variability of the signs "a," "o," and "u," which in many languages can exchange their phonetic value depending on placement, stress, dialect, and the vagaries of etymology. 
used for practicing cuneiform. The poem had everything a teacher could wish: sex, death, adventure, and good vocab.

The corpus of Sumerian poetry was preserved for a millennium after no one still spoke the language, because Sumerian was the origin of the cuneiform script used for the dominant (and linguistically unrelated) language of Akkadian. Akkadian words often contained characters that needed to be read for their Sumerian sound value and meaning rather than for their Akkadian values. Mastering this bilingual but monoscriptural system was an arduous process. Employing a reverse psychology that a modern teacher can admire, one Babylonian school text had students practice with a text that comically staged their own complaints:

The door monitor said, "Why did you go out without my say-so?" and he beat me.

The water-monitor said, "Why did you help yourself to water without my say-so?" and he beat me.

The Sumerian monitor said, "You spoke in Akkadian!" and he beat me. My teacher said, "Your handwriting is not at all good!" and he beat me. GEORGE, Epic of Gilgamesh, xviii

Those scribes who had survived the long apprenticeship in writing possessed a rare and prestigious knowledge, and these adepts seem to have taken little interest in the literatures of the smaller and poorer societies that employed alphabetic scripts. The very simplicity of the alphabetic scripts, the basis of their eventual victory over cuneiform and hieroglyphics alike, probably seemed to the cultivated Egyptian or Babylonian scribe to be a mark of lesser refinement and weaker expressive power. As with Chinese script, this power was visual as well as verbal. As early as Egypt's Fifth Dynasty in the early third millennium, hieroglyphs were being carved and painted on temples, tombs, and palaces in exquisite detail, down to the wrinkled feet of a little chick whose every feather could be lovingly highlighted, even though the chick simply stood for "w." More abstracted from their originally pictographic forms, the Sumerian/Akkadian signs were still used to great visual effect, with many styles of presentation and often running right across the bodies of kings and gods on relief carvings. ${ }^{2}$

2 It may be an oversimplification to speak of cuneiform as "a" script at all, as the system was never standardized. Different cities, and even particular scribal schools or families within a city, could have markedly different styles, the graphic equivalent of a local dialect; deci- 
These elaborate scripts enjoyed more than literary and artistic prestige. Not unlike Latin and classical Chinese, they had political value as elite writing systems, only available to people of substantial education and social standing, their complexity shielding messages from commoners' eyes. When a provincial governor wrote to Assyria's Sargon II in $710 \mathrm{BCE}$, asking if he could use the more convenient Aramaic instead of Akkadian, Sargon sharply reproved him: "[As to what you wrote]: ... 'if it is acceptable to the king, let me write and send my messages to the king on Aramaic parchment sheets' - why would you not write and send me messages in Akkadian? Really, your message must be drawn up in this very manner-this is a fixed regulation!" (Dietrich 5).

As Sargon's letter shows, scripts developed in tandem with the materials on which they were typically inscribed. Papyrus was plentiful in Egypt but rare elsewhere; the hieroglyphs fluently written with a brush on papyrus couldn't readily be inscribed on clay, the ubiquitous medium in Mesopotamia. Clay was easily formed into unbaked tablets, small or large, on which a reed stylus could quickly inscribe cuneiform signs. Cuneiform may look daunting today, but Mesopotamian and Hittite scribes were massively productive (libraries could contain tens of thousands of tablets), and literacy extended beyond court and temple circles to include merchants. Women as well as men might learn to write, with wives managing business at home and exchanging letters with their husbands on the road. A major court or temple library could contain tens of thousands of documents, and Mesopotamian scribes lived to write memos. No occurrence at court was too minor to record, as we see from the extensive documents recovered from the archives of Assyria's kings Esarhaddon and his son Ashurbanipal, who reigned in the seventh century вС Е: "To my lord the king .... Idri-aha'u came and brought the shoes in the evening of the 16th" (Luukko and Van Buylaere 124). Almost anything could provoke a dispute between rival bureaucrats, and the rivals regularly appealed to the king. When a new shipment of wine arrived at a time when the wine cellars were already full, the wine steward wrote that the king should command "that storage rooms be shown to us, so that we may proceed. There is much wine for the king - where should we put it?" (102).

Babylonian scribes in the second millennium freely translated back and forth between Sumerian and Akkadian, and as Akkadian became the lingua franca across the Fertile Crescent, scribes throughout the region developed

phering an unfamiliar style must often have been difficult for readers then as now. Carved hieroglyphics would be much easier going, but scribes in different Egyptian cities had very different styles for writing in the abbreviated cursive known as "hieratic." 
multilingual abilities based in a single script. They might also employ Aramaic on parchment as a kind of shorthand for everyday purposes, but serious writing was expected to be done in cuneiform, on tablets that could be preserved indefinitely if baked. The scribal culture that was grounded in cuneiform created a strong bond across societies like the Babylonian, Assyrian, and Hittite empires, whose leaders were often at each others' throats. As a result, even when Mesopotamia and the broader Fertile Crescent were politically fragmented under various competing regimes, it is appropriate to speak in literary terms of a single "cuneiform scriptworld." ${ }^{3}$

The early case of cuneiform shows a pattern that can be found in the spread of the Chinese writing system and other very successful scripts since then: a hegemonic script can far outrun the boundaries of its homeland. Once adopted in satellite or peripheral areas, a dominant script often functions in two quite different ways at once, both suppressing local traditions and yet often also stimulating them in new ways. The introduction of literacy, or simply the adoption of a more practical or prestigious technology for writing, brings in foreign texts and traditions that may override the indigenous tradition. Yet it can also become a powerful force for cultural cohesion in its adopted territory, giving a common literary culture to groups who formerly had differing scripts or none at all. When they were forced to adopt the Roman alphabet in colonial New Spain, the Mexica, Zapotecs, and Maya gained a common writing system far easier to learn and employ than their incompatible hieroglyphic systems. They could more readily learn and read each others' languages, and over time, literacy could spread far beyond the elite circles that had formerly mastered the old glyphs. In northern Europe, runes had been developed in angular forms suitable for carving on branches or grainy boards, but weren't thought of as a vehicle for extended literary composition. When the Roman alphabet and the attendant use of parchment spread northward toward the end of the first millennium CE, Scandinavian and British writers realized the advantages of preserving formerly oral tales and poems in writing - a discovery that stimulated new compositions in runes in the ninth and tenth centuries before the Roman alphabet definitively won out.

As the essays in this issue show, Chinese literrary compositions had an enormous influence on writers beyond China's own borders, an influence increased by their ability to revocalize the Chinese characters to suit their own languages. Thus Japanese literati developed elaborate diacritical marks to indicate pre-

3 On the development and uses of cuneiform, see Jean Bottéro, Mesopotamia: Writing, Reasoning, and the Gods, and Clarisse Herrenschmidt, Les Trois écritures. 
ferred readings of Chinese characters, enabling them in effect to transpose Chinese texts into Japanese without having to translate them, as would have been necessary with a more purely phonetic system (Denecke, chapter 1). Around East Asia, the Chinese characters were adapted to local uses, and Japanese or Korean or Vietnamese literati could choose to write either classical Chinese or their own vernacular in their modified or mixed scripts. Even these localized versions of writing retained a strong awareness of connection to culture of classical Chinese.

As an example, consider "A Record of the Bamboo in the Bamboo Arbor of the Wŏltŭng Monastery," a prose text written in Chinese by a Korean monk named Sigyŏngam (c. 1270-1350). In this text, Sigyŏngam's teacher is contemplating a bamboo grove on a hillside, and he asks his disciples to describe the qualities of bamboo. One praises its usefulness, one praises its beauty, one its delicious taste, one its ability to endure in all kinds of weather. Finally Sigyŏngam speaks up, opting for a more spiritual meaning:

Sigyŏngam said, "If I love the bamboo for its flavor, its usefulness, elegance, and integrity, all I get is externals, not its essence. When I look at the grace and height of a shoot since its sprouting, I realize how the embedded seed, once awakened, makes sudden progress. I look at it growing tougher as it ages, and I understand how cultivated power increases gradually. Its hollowness indicates that nature is empty. From its upright appearance, it is possible to deduce the true form of things .... My love of the bamboo stems not from what the four gentlemen have said, but from my own observations."

The master remarked, "How profound! You are indeed a devoted friend of the bamboo." I hasten to write these remarks down on the board as a model for future lovers of bamboo.

LEE 55

In hastening to write down his observation, Sigyŏngam illustrates the interplay between the local and the regional within the broad sinographic world. He stresses that he is reporting the fruits of his own direct observation, but the entire dialogue is composed within the tradition of Chinese philosophical discourses that came to Korea in the wake of Buddhism, with the master pleased by his most perceptive follower's reply. Sigyŏngam's “own observations" embody Buddhist ideas of emptiness, enlightenment, and the power of discernment of the true nature of things beneath the surface, which he can make his own by the combination of his personal experience and his ability to record this experience in the Chinese language and script. Further, this dialogue may 
have a material as well as a cultural basis. At the time he was writing in the early fourteenth century, a period of drought in northern China was limiting the growth of bamboo, which continued to flourish in Korea, and there may be an element of local pride in Korea's ability to produce this essential plant, used for the brushes employed by painters and poets alike; he then writes his text on a home-grown board. ${ }^{4}$

In East Asia as elsewhere, the imported literary tradition could become a resource for the creation of a newly independent national literature. This possibility is exemplified by the foundational work of modern Vietnamese literature, Nguyen Du's Đoạn Trường Tân Thanh (斷腸新聲, “A New Cry From a Broken Heart”), usually called Truyện Kiều (傳趣), or The Tale of Kieu (c. 1810), a verse adaptation of a seventeenth-century Ming Dynasty novel, Jin Yun Qiao (金雲趐), written in classical Chinese by a writer using the pen name Qingxin Cairen (青心才人, Pure-hearted Man of Talent). In creating his verse narrative, Nguyen Du made far-reaching changes to his source. He wrote The Tale of Kieu not in Chinese but in Vietnamese, using Chũ Nôm, the Vietnamese script derived from the Chinese script, and he employed a local oral form known as the luc bát or "six-eight," with couplets of six syllables in the first line and eight in the second. Nguyen Du's ambitious reframing of his Chinese source text was part of a general movement by the writers of his era to create a literature of their own by refashioning the Chinese literary heritage in which they had been trained. As John Balaban has noted,

While concurring on the prestige of Chinese writing, Vietnamese literati were intent on establishing the independence of Vietnamese writing, even as they accepted models from the full range of Chinese literary forms, especially the "regulated verse" form, or lüshi, of the Tang dynasty ... The form reached aesthetic heights in Vietnamese hands in the 19th century, with poets such as the concubine Ho Xuan Huong, who composed regulated verse poems that were complete double entendres, filled with tonal puns (noi lai). Still others created regulated verse palindromes that would be in Vietnamese from start to finish but then, going backward, ideogram by ideogram, became poems in Chinese, switching languages on the reversal.

BALABAN

4 I owe the observation on the drought in China and the flourishing of Korean bamboo at this time to discussion following a presentation to the Research Institute for Korean Studies at Korea University in August 2010. 
As an adaptive transformation of a Chinese novel, written in Chũ Nôm, The Tale of Kieu is a major document from the Chinese scriptworld-though it has been little discussed by scholars in China, who (if they know of it at all) mostly consider it as a mere translation of a minor work of Chinese fiction. ${ }^{5}$ Yet Nguyen Du turned the story to dramatically new uses for himself and his culture. In his hands, the tale reflects Vietnam's long struggle for independence from China and also the new reality of the growing influence of the French, who had provided support to overthrow the Le Dynasty in Vietnam not long before Nguyen Du began his poem. Having worked as an official in the older dynasty, Nguyen Du had reluctantly begun working for its successor, the Nguyen Dynasty (no relation to Nguyen Du himself), evidently concluding that lingering loyalty to the deposed dynasty would not help rescue the country from chaos.

In retelling the story of Kieu, Nguyen Du not only adapted a novel from Chinese prose into Vietnamese verse, but he translated his own experiences into hers. Kieu's romantic struggles implicitly reflect his own political turmoil; she has to sell herself into prostitution to redeem her family from gambling debts, then she has a series of misadventures and love affairs before finally becoming reunited with her first love. The political dimension is made explicit when Kieu advises one of her lovers, a rebel warlord, to submit to the Emperor, an accommodation that she hopes will bring some stability to her own life as well as that of her lover:
"A fern that floats on water," she now thought,
"I've wandered long enough, endured enough.
Let's swear allegiance to the Emperor's throne-
We'll travel far up fortune's royal road.
Public and private ends will both be met."

274

Kieu is tragically mistaken, however, as the Emperor's seeming overture of peace and reconciliation is in reality a fatal trap for her lover.

Even as he shapes Kieu's story to reflect his own circumstances, Nguyen Du makes clear his deep connection to the Chinese tradition throughout the novel. It is interesting that as a male poet on the periphery of the Sinophone world, Nguyen Du more than once identified himself with female Chinese artists. Not only is the fictional Kieu an accomplished poet, calligrapher, and

5 I thank Professor Nam Nguyen of Ho Chi Minh City University for this information. 
lutenist; Nguyen Du also identified with an actual woman poet, Hsiao-Ching, a seventeenth-century poet who was forced to become a concubine to a man whose jealous primary wife burned almost all of her poems. In a poem called "Reading Hsiao-Ching," Nguyen Du reflects on her fate, and his own:

West Lake flower garden: a desert, now.

Alone, at the window, I read through old pages.

A smudge of rouge, a scent of perfume, but

I still weep.

Is there a fate for books?

Why mourn for a half-burned poem?

There is nothing, there is no one to question, and yet this misery feels like my own.

$\mathrm{Ah}$, in another three hundred years

will anyone weep, remembering my fate?

NGUYEN $25^{2}$

Nguyen Du's identification with a great female predecessor is mirrored in the opening scene of The Tale of Kieu itself, in which Kieu goes to visit the shrine of a famous lutenist, Dam Tien, who had died shortly before her marriage to a suitor (interestinbgly, someone who had come "from overseas" to woo her, 254). Feeling a kindred spirit in Dam Tien, Kieu pulls out a hairpin and engraved "four lines of stop-short verse" (a Vietnamese folk form) on a tree beside her predecessor's tomb (255). Miraculously, this act of poetic piety causes Dam Tien to manifest herself, and to write an answering poem of her own:

A poet's feelings, rife with anguish, flowed:

She carved an old-style poem on the tree.

256

Still fully within the Chinese scriptworld in the early nineteenth century, Nguyen Du is keenly aware of the ancient authority of the imperial center of "the Middle Kingdom" and the novelty of his poetic enterprise.

In a key scene in the novel, Kieu's poetic ability saves her before a judge who is about to condemn her to be returned to the brothel where she's been forced to work. The judge is impressed that "though just a lowly woman," she is skilled both as an artist and as a poet.

"But she must be perfection!" laughed the judge.

"Well, write a piece, The Cangue, and strut your art." 
The girl complied — she raised the brush and wrote, Then laid the sheets of paper on his desk.

"It tops the height of T'ang!" he cried in praise. 267

The act of writing is here emphasized if anything more than the content being written.

While The Tale of Kieu broadly follows the outlines of its Chinese source, Nguyen Du elevated Kieu to be his central character, over her warlord lover who dominates the Chinese novel, and he significantly changed the story's ending, having Kieu finally renounce her still loyal first love, Kim. She persuades him to marry her sister, so that she can live with them as a Buddhist nun, free from romantic attachments - a notable departure from the reunion and marriage with which the Chinese novel ends. Throughout the poem, Nguyen Du emphasizes Kieu's exceptional physical charms along with her artistic ability, often comparing her to a blossoming flower, but these images are given a Buddhist emphasis on transience and renunciation rather than on erotic fulfillment: flowers bloom but then fade, bees invade their innermost recesses, reeds are flattened by the north wind, bamboos split and tiles slip from roofs.

A founder of vernacular Vietnamese poetry written in Chữ Nôm, Nguyen $\mathrm{Du}$ was also a devotee of the classical Chinese canon that he evokes on every page. Yet in making Kieu an emblem for an oppressed people, he envisions a country very different from imperial China - or from Napoleonic France, with their quest for economic gain and political dominance. Nguyen Du is at once a proud member of the "Sinitic cosmopolis" and an innovator in Vietnamese verse, a poet of passion and of renunciation, political engagement and withdrawal, his creative innovation fuelled by the interfusion of foreign and local traditions.

A century later, during the period of anticolonial struggle against the French, The Tale of Kieu was transliterated from Chũ Nôm into the newly dominant alphabetic script, chữ Quốc ngữ ("National language script"). Though this script had been developed in the sixteenth century by Jesuit missionaries for purposes of conversion (see Phan in this issue), it gained little purchase before the early twentieth century, when it came to be embraced by anticolonial intellectuals as helping them to reach the masses and promote political action against the very foreigners who had introduced the alphabet, and by 1930 it was the sole script in general use. Reading The Tale of Kieu in the new transliteration, the activist poets of mid-century Vietnam looked back to Nguyen Du as an inspiring figure in the struggle for Vietnamese independence from foreign control. A good expression of this view is "Thoughts on Nguyen," by Che Lan Vien (1920- 
1989), who was active in the struggle for independence from Japanese rule in the 1940s and then became a leader in the leftist Vietnamese Writer's Association:
Born into those foul times of dusk and dust, you reached and touched no soul mate by your side. Your sorrow matched the fate of humankind: Kieu spoke your thoughts and crystallized your life. Kings rose and fell—the poem still abides. You fought and won your feats on waves of words. You planted stakes in the Bach-dang of time: our language and the moon forever shine.

Che Lan Vien here associates Nguyen Du with the great commanders Ngô Quyền and Trần Hưng Đạo, who in 938 and 1288, respectively, had planted stakes in northern Vietnam's tidal Bach Dang River to impale invading Chinese ships and preserve their country's independence. Proud though he is of his poetic ancestor's accomplishment, Che Lan Vien isn't so happy with Nguyen Du's choice of a Chinese source for his work. He goes on to ask:
Why borrow foreign scenes? Our land flows not with one Ch'ien'-t'ang but many fateful streams. Why split yourself? Nguyen Du, To Nhu, Thanh Hien: the tears in Kieu merge all three into one. Need we one century more to feel for Nguyen? Mourning our nightfalls, we soon grieve for his. We love kings's calls to arms, yet we shall not forget those frost-white reeds along Kieu's road. CHE LAN VIEN 282

As a committed nationalist, Che Lan Vien would have preferred for the foundational work of modern Vietnamese literature to have used local traditions rather than a foreign source at all. Recalling the several pen names that Nguyen Du used (partly to avoid censorship), Che Lan Vien suggests that his predecessor unduly "split himself" between Chinese and Vietnamese traditions.

Nguyen Du himself would never have experienced his writing as such a "splitting," since Vietnamese literati of his era proudly considered literary Chinese as part of their own heritage. Even though he was writing in Vietnamese and using a local verse form, he was still very much a part of the Chinese scriptworld, both in terms of the script itself and of the educational system 
that conveyed so much cultural knowledge together with literacy. But Che Lan Vien, writing — and reading The Tale of Kieu itself—in Quốc ngũ rather than the abandoned Sinitic Chữ Nôm, understands the poem as an act of resistance to the very culture from which it took its literary model.

Comparable struggles over identity and cultural memory occurred in Korea as a rising nationalism led to a substantial (though never total) shift away from the Chinese scriptworld. The alphabetic Korean script commissioned by King Sejong in the 1440s didn't displace Chinese script for many years. For centuries, Korean writers such as Sigyŏngam continued to think of themselves as part of the Chinese scriptworld, but by the 1920 s the ability to read the classical Chinese script was becoming a thing of the past for all but a few Korean intellectuals. As most surviving premodern Korean literature is written in Chinese characters, this change made the majority of earlier texts by Korean writers unreadable to their successors, a loss paralleling that entailed in what Geoffrey Lewis (1999) as well described as the "catastrophic success" of the Kemalist language reform in Turkey during the same period. A vivid expression of the sense of foreignness of writing in Chinese script can be seen in a poem by Pak Tujin (1916-1998), entitled "Book of Poems":

A book of poems lay open

white on the sand before the blue sea.

Wind turned the pages,

ruffling them one by one.

The warm words in the book had etched within them

a sad and beautiful heart.

Those printed words became birds, began to fly.

One, then another,

a hundred, a thousand,

higher, higher, glimmering, drawn into the sky

white poems of birds, birds of poems.

Flower petals fell trembling from the sky.

Those birds that had recited poems in the sky forgetting, unable to speak the verse they knew became flowers falling above the sea.

Then they became stars in the far distant sky.

Those birds that had recited poems in the sky the world's sad and beautiful poems, recited the poems in the book so brightly they twinkled now, stars in the world of stars.

MCCANN 128 
A hegemonic script creates a scriptworld during the centuries of its use, and it can linger in memory even if a new script comes to take its place, as the Ottoman script continued to do for Ahmet Hamdi Tanpınar, Orhan Pamuk, and other modern Turkish writers (see Ertürk, Grammatology), or Hebrew script for assimilated Jewish-American writers, as Hana Wirth-Nesher has shown in Call It English. As Proust remarks near the end of the Recherche du temps perdu, the true paradises are those that we've lost. Though Pak Tujin was a leader in the struggle for Korea's independence and its cultural integrity during the period of Japanese occupation, several of his poems voice his concern for the loss of cultural memory following the eclipse of Chinese in favor of the Hangul script. His poem "Inscription Etched by Water" can provide a closing image of the persisting power of the Chinese scriptworld, even for a poet who can no longer read the script:

One stroke at a time, now and then in spare moments

retracing the strokes with water

during ten times a hundred thousand years

I wrote

one word.

After a time, later again

quietly searching out the place, then

my hand's touch exploring gently,

retracing each of the strokes,

after passing yet again ten times a hundred thousand years,

I wrote one word.

In the etched form of each stroke gleamed

a gorgeous rainbow,

in the sun's rays lighting the water

a rainbow of the currents.

There were the times once when I listened,

inclined my ear to the messages, but

having heard

then afterward, and afterward

recorded the inner sense of those words,

now I find that

after carving a few ancient characters

year upon year, for too long,

I have completely forgotten

what words I wrote.

MCCANN 126-27 


\section{Works Cited}

Balaban, John. “Vietnamese Literature." Encyclopaedia Britannica Online. Web. 18 Oct., 2015 .

Bottéro, Jean. Mesopotamia: Writing, Reasoning, and the Gods. Trans. Zaineb Bahrani and Marc Van De Mieroop. Chicago: University of Chicago Press, 1992.

Che Lan Vien, “Thoughts on Kieu." In David Damrosch et al., eds., The Longman Anthology of World Literature. New York: Pearson Longman, 2d. ed., 2009, vol. E, 282-3.

Damrosch, David. "Scriptworlds: Writing Systems and the Formation of World Literature." Modern Language Quarterly 68: 2 (2007), 195-219.

Damrosch, David. "Global Scripts and the Formation of Literary Traditions." In Approaches to World Literature, ed. Joachim Küpper. Berlin: Akademie Verlag, 2013, 85-102.

Denecke, Wiebke. Classical World Literatures: Sino-Japanese and Greco-Roman Comparisons. Oxford: Oxford UP, 2013.

Dietrich, Manfred, ed. The Babylonian Correspondence of Sargon and Sennacherib. Helsinki: Helsinki UP, 2003.

Ertürk, Nergis. Grammatology and Literary Modernity in Turkey. Oxford and New York: Oxford UP, 2011.

George, Andrew. The Babylonian Gilgamesh Epic: Introduction, Critical Edition, and Cuneiform Texts, 2 vols. Oxford: Oxford UP, 2003.

George, Andrew. The Epic of Gilgamesh. London and New York: Penguin, 1999.

Herrenschmidt, Clarisse. Les Trois écritures: langue, nombre, code. Paris: Gallimard, 2007.

Lee, Peter H., ed. Anthology of Korean Literature: From Early Times to the Nineteenth Century. Honolulu: University of Hawai'i Press, 1981.

Lewis, Geoffrey. The Turkish Language Reform: A Catastrophic Success. Oxford: Oxford UP, 1999.

Luukko, Mikko, and Greta Van Buylaere. The Political Correspondence of Esarhaddon. State Archives of Assyria 16. Helsinki: Helsinki UP, 2002.

McCann, David R., ed. The Columbia Anthology of Modern Korean Poetry. New York: Columbia UP, 2004

Nguyen Du. "Reading Hsiao-Ching" and selections from The Tae of Kieu. In The Longman Anthology of World Literature, eds. David Damrosch et al. New York: Pearson Longman, 2d. ed., 2009, vol. E, 252-82.

Wirth-Nesher, Hana. Call It English: The Languages of Jewish American Literature. Princeton: Princeton UP, 2008. 